\title{
Fusarium Wilt Disease of Banana: Current Development of Fusarium Resistant Banana
}

\author{
Poon $\mathrm{NK}^{1}$ and Teo $\mathrm{CH}^{2 *}$ \\ ${ }^{1}$ Institute of Biological Sciences, Faculty of Science, University of Malaya, Malaysia \\ ${ }^{2}$ Centre for Research in Biotechnology for Agriculture (CEBAR), University of Malaya, \\ Malaysia
}

*Corresponding author: Chee How Teo, Centre for Research in Biotechnology for Agriculture (CEBAR), University of Malaya, 50603 Kuala Lumpur, Malaysia, Tel: +603 7967 2701; Email: cheehow.teo@um.edu.my

\section{Mini Review \\ Volume 4 Issue 1}

Received Date: December 25, 2018

Published Date: January 16, 2019

DOI: $10.23880 /$ oajmb-16000134

\section{Abstract}

Fusarium wilt of banana constantly causing considerable losses on banana industry of both local and global markets. Global exportation of banana was greatly affected by this disease since 1950s. After the emergence of a hypervirulent Tropical Race 4 strain of Fusarium oxysporum f. sp. cubense, many genetic improvements aiming to create resistant cultivars were attempted, mainly through transgenic approach. This review provides the recent finding of potential resistant genes and various efforts in creating resistant cultivar from year 2008 to year 2018.

Keywords: Banana; Fusarium wilt; Resistance

\section{Introduction}

Banana is a very popular fruit crops. According to FAO, banana is ranked eight on the list of most important food crop globally and it's the fourth most important crop for the least developed countries. Globally, nearly $85 \%$ of the annual banana production was consumed locally and only less than 15\% were exported (FAOSTAT, 2015). Exportation of banana is frequently being hampered by the fact that banana is highly susceptible to diseases caused by various pathogens (fungi, bacteria, viruses and nematodes). Disease is the major biotic constraints facing by banana export trade where it first obvious setback traced back to the loss of Gros Michel to Fusarium oxysporum f. sp cubense race 1 in 1950s [1]. Currently, almost all bananas traded internationally and a considerably part of locally consumed bananas is of Cavendish and other cultivars with no resistance towards F. oxysporum f. sp cubense Tropical Race 4 (FocTR4). Many studies have been conducted to screen potential resistance gene candidates in banana germplasm. Genetic improvement programs are aiming at creating new resistant varieties. The source of resistance gene comes from two directions, the resistance gene analogues from wild relatives of banana which can be identified with a NBS-LRR domain, and other broad-spectrum resistance genes which response after a pathogen invasion.

\section{Impacts of Fusarium Wilt on Banana Industry}

In early 1990s, the occurrence of FocTR4 epidemic in Malaysia collapsed a then newly established Cavendish exportation effort which targeted the expanding East Asia and Middle East market in merely 2 years' time [2]. Since the infection of the FocTR4 is irreversible and untreatable for decades [3], its economy impact is profound where not restricted to the losses related to yields but also the gradual losses of arable lands for banana. FocTR4 is known to infect non-host species such as weeds and these 
asymptomatic species will act as an reservoir of inoculum which in turn spread to nearby uninfected lands and water sources $[4,5]$.

Two decades ago, FocTR4 first occurred and was restricted in Asian banana producing countries such as Malaysia and Indonesia, as well as Northern Australia. But since late 2013, FocTR4 was reportedly found outside of South East Asia and Pacific Areas for the first time. Incidences caused by FocTR4 were spotted from Middle East [6,7] and then crept into Africa [8]. In Malaysia, a country-wide survey carried out in year 2008-2009 showed that around 883 hectares of banana plantation lands were infected with Fusarium wilt. This costed the country's banana industry about USD14.1 million losses per annual. Constraint the disease incured additional cost to producers and causing small holders to cease operation due to insustainability [1]. Also, diseased plants with lower yields and quality significantly reduce the incomes of growers and adversely impact the banana industry on both local and international levels.

\section{Transgenic Efforts in Fusarium Wilt Resistance}

The establishment of resistant banana cultivar is usually performed through transgenic studies since conventional breeding approaches are not applicable to banana because most of the commercial cultivars are sterile and seedless. The resistance gene candidates consist of those have potential to offer broad-spectrum resistance and those provide the banana with specific resistant against Foc. Efforts are also been made on studying the potential of manipulating plant defense pathway such as salycylic acid pathway to heighten the response of banana towards broad range pathogen particularly Foc invasion [9-11].

Generally, the transgenes transformed into banana plant for Foc resistance were coding for broad-spectrum antimicrobial or antifungal peptide (Table 1). The transgenic bananas generated were all specifically tested for Fusarium wilt resistant trait but they might potentially carrying a broad-range pathogen resistance. Dale et al. (2017) [12] reported a transgenic Cavendish banana carrying RGA2 transgene showing promising Fusarium wilt resistance after a 3 year field trial. In the Cavendish banana, 3 endogenous RGA2 homologues were present in addition of the transgenic cassette. But it was found that the native expression of $R G A 2 \mathrm{~s}$ were 10 folds lower than the $R G A 2$ transgene driven by a maize polyubiquitin promoter (Ubi-P). The over expression of $R G A 2$ have no detrimental effect on the banana growth and bunch size.

\begin{tabular}{|c|c|c|c|c|c|}
\hline Transgene & Source & Function & Banana cultivar & $\begin{array}{c}\text { Resistance } \\
\text { assessment stage }\end{array}$ & References \\
\hline $\begin{array}{l}\text { Plant ferredoxin-like } \\
\text { protein }(p f l p)\end{array}$ & Capsicum annuum & antimicrobial peptide & cv. Pei Chiao (AAA) & $\begin{array}{l}\text { Greenhouse } \\
\text { bioassay }\end{array}$ & [13] \\
\hline $\begin{array}{c}P R 5 \text { or Thaumatin-like } \\
\text { proteins (TLPs) }\end{array}$ & Oryzae sativa & Antifungal activity & $\begin{array}{c}\text { Pisang Nangka } \\
\text { (AAB) }\end{array}$ & $\begin{array}{l}\text { Greenhouse } \\
\text { bioassay }\end{array}$ & [14] \\
\hline Petunia floral defensins & Petunia hybrida & Antimicrobial peptide & cv. Rasthali (AAB) & $\begin{array}{l}\text { Greenhouse } \\
\text { bioassay }\end{array}$ & [15] \\
\hline Synthetic dsRNAmolecules & - & $\begin{array}{l}\text { dsRNA targeting } \\
\text { adenylate cyclase }\end{array}$ & - & $\begin{array}{c}\text { In vitro Foc } \\
\text { inhibition assay }\end{array}$ & [16] \\
\hline \multirow{2}{*}{ Ace-AMP1 } & \multirow{2}{*}{ Allium cepae } & \multirow{2}{*}{ Antimicrobial peptide } & \multirow{2}{*}{ cv. Rasthali (AAB) } & \multirow{2}{*}{$\begin{array}{l}\text { Greenhouse } \\
\text { bioassay }\end{array}$} & [17] \\
\hline & & & & & [18] \\
\hline Endochitinase gene (chit42) & $\begin{array}{l}\text { Trichoderma } \\
\text { harzianum }\end{array}$ & Antifungal activity & cv. Furenzhi (AA) & $\begin{array}{l}\text { Greenhouse } \\
\text { bioassay }\end{array}$ & [19] \\
\hline \begin{tabular}{|c|}
$\begin{array}{c}\text { Small interfering RNAs } \\
\text { (siRNAs) }\end{array}$ \\
(ihpRNA-VEL and ihpRNA- \\
FTF1
\end{tabular} & - & Silence vital fungal genes & cv. Rasthali (AAB) & $\begin{array}{l}\text { Greenhouse } \\
\text { bioassay }\end{array}$ & [20] \\
\hline \begin{tabular}{|c|} 
Cell-death genes \\
(MusaDAD1, MusaBAG1 and \\
MusaBI1) \\
\end{tabular} & Musa acuminata & $\begin{array}{l}\text { cell-death-related and } \\
\text { highly induced by Foc } \\
\text { infection }\end{array}$ & cv. Rasthali (AAB) & $\begin{array}{l}\text { Greenhouse } \\
\text { bioassay }\end{array}$ & {$[21]$} \\
\hline
\end{tabular}




\section{Open Access Journal of Microbiology \& Biotechnology}

\begin{tabular}{|c|c|c|c|c|c|}
\hline Defensin gene (Sm-AMP-D1) & Stellaria media & Antimicrobial peptide & cv. Rasthali (AAB) & $\begin{array}{c}\text { Greenhouse } \\
\text { bioassay }\end{array}$ & [22] \\
\hline Ced9 & $\begin{array}{c}\text { Caenorhabditis } \\
\text { elegans }\end{array}$ & antiapoptosis & cv. Grand Nain & Field trial & [23] \\
\hline Resistance gene analogues & Musa acuminata \\
ssp. malaccensis & $\begin{array}{c}\text { nucleotide-binding and } \\
\text { leucine-rich repeat (NB- }\end{array}$ & $\begin{array}{c}\text { LRR -type resistance (R) } \\
\text { gene }\end{array}$ & cv. Grand Nain & Field trial & [24] \\
\hline
\end{tabular}

Table 1: Transgenes used in generate Fusarium wilt resistant transgenic banana.

A more targeted approach is the utilization of RNAmediated gene silencing contruct to interupt vital fungal genes. Two intron hairpin-mediated expression of small interfering RNA (siRNAs) were constructed by Ghag et al. (2014a) [20] and transformed into embryogenic cell suspensions of banana cv. Rasthali via Agrobacteriummediated transformation. Transformants were selected in vitro, acclimatized and subject to Foc bioassay to confirm the resistance. Foc vital genes velvet and Fusarium transcription factor 1 were silenced by the siRNAs expressed from the transgenic host and the siRNAs was able to translocate into the cytosol of Foc. This sequencetargeted approach has advantage over the broadspectrum antimicrobial genes transgenic approach as the construct is strictly targeting vital Foc genes and will have no risk in wipe out other beneficial symbionts of banana.

While the other utilized transgene to confer Fusarium wilt resistant to existing cultivars, Chen, et al. (2013) [25] utilized ethyl methane sulphonate (EMS) to induce mutations in plantlets of banana, cv. Brazil. The induced micro-cross-sections of pseudostem were regenerated and 5 Fusarium resistant lines were identified from early screening technique followed by a bioassay. However, all resistant lines generated still produce certain amount of regenerants which showing disease symptoms, ranging from $7 \%$ to $34 \%$ of disease incidences. The major drawbacks of induced mutations are the untraceable random mutation in the genome thus the effects on the plant other than Fusarium-resistant are difficult to be predicted.

Apart from antimicrobial peptide-encoding genes, miRNAs are promising candidates since they potentially regulating the plant response toward biotic stresses. But overexpression of a common miRNA, Musa miRNA156 resulted in transgenic plant with abnormal leaf anatomy and stunted growth [26]. This infered the importance of careful assessments on the potential detrimentral effects of transgenic plants with desired wilt resistance traits before disseminate for cultivation.

\section{Future Works}

Fusarium wilt will continuously causing losses in banana industry unless a resistant cultivar can be generated and mass cultivated successfully in a reliable way. Although most of the transgenic banana improvement projects were carried out up to the greenhouse trials, specifically the screening for Foc resistance. However, a more thorough assessments are needed to assess the possible deleterious effects of transgenes on banana quality and yield, their impacts on banana natural microbiomes or rhizospheres and the environments, and lastly the biosafety of transgenic bananas.

\section{References}

1. Ploetz RC (2015) Fusarium wilt of banana. Phytopathol 105(12): 1512-1521.

2. Molina AB, Fabregar E, Sinohin VG, Yi G, Viljoen A (2009) Recent occurrence of fusarium oxysporum $f$. sp. cubense tropical race 4 in asia. Acta horticulturae 828(828): 109-116.

3. Stover RH (1962) Fusarial wilt (Panama disease) of bananas and other Musa species. Commonwealth Mycological Institutes, England, pp: 117.

4. Waite BH, Dunlap VC (1953) Preliminary host range studies with Fusarium oxysporum f. sp. cubense. Plant Dis Rep 37: 79-80.

5. Schippers B, van Eck WH (1981) Formation and survival of chlamydospores in Fusarium. In: Nelson PE, et al. (Eds.), Fusarium: Diseases, Biology and Taxanomy, Penn State Univ Press, University Park, pp: 250-260.

6. Garcia FA, Ordonez N, Konkol J, Al Qasem M, Naser Z, et al. (2014) First Report of Fusarium oxysporum $\mathrm{f}$. sp. cubense Tropical Race 4 associated with Panama 


\section{Open Access Journal of Microbiology \& Biotechnology}

Disease of banana outside Southeast Asia. Plant Dis 98(5): 694 .

7. Ordonez N, Garcia FA, Laghari H, Akkary M, Harfouche EN, et al. (2016) First report of Fusarium oxysporum f. sp. cubense tropical race 4 causing Panama disease in cavendish bananas in Pakistan and Lebanon. Plant Dis 100(1): 209.

8. Zheng SJ, García-Bastidas FA, Li X, Zeng L, Bai T, et al. (2018) New geographical insights of the latest expansion of Fusarium oxysporum f.sp. cubense tropical race 4 into the greater Mekong subregion. Front Plant Sci 9: 457.

9. Endah R, Beyene G, Kiggundu A, van den Berg N, Schlüter U, et al. (2008) Elicitor and Fusariuminduced expression of NPR1-like genes in banana. Plant Physiol Biochem. 46(11): 1007-1014.

10. Radhajeyalakshmi R, Xia Y, Shah D (2014) Evidence of salicylic acid regulatory mechanisms of disease resistance against banana vascular wilt Fusarium oxysporium f.sp. cubense in Arabidopsis thaliana. African Journal of Biotechnology 13(30): 3030-3025.

11. Wang Z, Jia C, Li J, Huang S, Xu B, et al. (2015) Activation of salicylic acid metabolism and signal transduction can enhance resistance to Fusarium wilt in banana (Musa acuminata L. AAA group, cv. Cavendish). Functional \& Integrative Genomics 15(1): 47-62.

12. Dale J, James A, Paul JY, Khanna H, Smith M, et al. (2017) Transgenic Cavendish bananas with resistance to Fusarium wilt tropical race 4. Nat Commun 8: 1496.

13. Yip MK, Lee SW, Su KC, Lin YH, Chen TY, et al. (2011) An easy and efficient protocol in the production of pflp transgenic banana against Fusarium wilt. Plant Biotechnol Rep 5(3): 245-254.

14. Mahdavi F, Sariah M, Maziah M (2012) Expression of rice thaumatin-like protein gene in transgenic banana plants enhances resistance to fusarium wilt. Appl Biochem Biotechnol 166(4): 1008-1019.

15. Ghag SB, Shekhawat UK, Ganapathi TR (2012) Petunia floral defensins with unique prodomains as novel candidates for development of fusarium wilt resistance in transgenic banana plants. PLoS One 7(6): 39557.
16. Mumbanza FM, Kiggundu A, Tusiime G, Tushemereirwe WK, Niblett C, et al. (2013) In vitro antifungal activity of synthetic dsRNA molecules against two pathogens of banana, Fusarium oxysporum f. sp. cubense and Mycosphaerella fijiensis. Pest Manag Sci 69(10): 1155-1162.

17. Mohandas S, Sowmya HD, Manjula R, Pratibha KY, Meenakshi S, Ajay KM (2011) Development of highly regenerative embryogenic cell suspensions of'Nanjangud Rasbale' (syn. 'Rasthali', Musa, AAB, Silk subgroup) and transfor-mants with AMP gene. Acta Hortic 897: 245-253.

18. Mohandas S, Sowmya HD, Saxena AK, Meenakshia S, Rani RT, et al. (2013) Transgenic banana cv. Rasthali (AAB, Silk gp) harboring Ace-AMP1 gene imparts enhanced resistance to Fusarium oxysporum f.sp. cubense race 1. Sci Hortic-Amsterdam 164(17): 392399.

19. Hu CH, Wei YR, Huang YH, Yi GJ (2013) An efficient protocol for the production of chit42 transgenic Furenzhi banana (Musa spp. AA group) resistant to Fusarium oxysporum. In Vitro Cellular and Developmental Biology Plant 49(5): 584-592.

20. Ghag SB, Shekhawat UK, Ganapathi TR (2014a) Hostinduced post-transcriptional hairpin RNA-mediated gene silencing of vital fungal genes confers efficient resistance against Fusarium wilt in banana. Plant Biotechnol J 12(5): 541-553.

21. Ghag SB, Shekhawat UK, Ganapathi TR (2014b) Native cell-death genes as candidates for developing wilt resistance in transgenic banana plants. AoB Plants 6: 037.

22. Ghag SB, Shekhawat UKS, Ganapathi TR (2014c) Transgenic banana plants expressing a Stellaria media defensin gene (Sm-AMP-D1) demonstrate improved resistance to Fusarium oxysporum Plant Cell Tiss Organ Cult 119(2): 247-255.

23. Paul JY, Becker DK, Dickman MB, Harding RM, Khanna HK, et al. (2011) Apoptosis-related genes confer resistance to Fusarium wilt in transgenic 'Lady Finger' bananas. Plant Biotechnol J 9(9): 1141-1148.

24. Peraza-Echeverria S, Dale JL, Harding RM, Smith MK, Collet C (2008) Characterization of disease resistance gene candidates of the nucleotide binding site (NBS) type from banana and correlation of a transcriptional polymorphism with resistance to Fusarium 
oxysporum f.sp. cubense race 4. Mol Breed 22: 565579.

25. Chen YF, Chen W, Huang X, Hu X, Zhao JT, et al. (2013) Fusarium wilt-resistant lines of Brazil banana (Musa spp., AAA) obtained by EMS-induced mutation in a micro-cross-section cultural system. Plant Pathol 62(1): 112-119.
26. Ghag SB, Shekhawat UK, Ganapathi TR (2015) Small RNA Profiling of Two Important Cultivars of Banana and Overexpression of miRNA156 in Transgenic Banana Plants. PLoS One 10(5): 0127179. 